\title{
STRUKTUR, ESTETIKA, DAN PERUBAHAN KONTEKS DALAM WACANA PIDATO UPACARA PERKAWINAN MASYARAKAT JAWA
}

\author{
Mulyana \\ FBS Universitas Negeri Yogyakarta \\ email:mul_mj@yahoo.com
}

\begin{abstract}
This study aims to describe language use in a wedding ceremony in terms of linguistic elements making a speech discourse possess Javanese literary esthetics and expressions of contexts and changes occurring in wedding ceremonies conducted by Javanese people. This study employed a sociolinguistic approach involving discourse analysis. It used data obtained from wedding ceremony speeches. The speeches were documented directly from Javanese wedding ceremonies in the area of Yogyakarta. The results of the data analysis are as follows. First, the spoken languages in Javanese wedding ceremonies include Javanese, Indonesian, and a mixed language called Jawindo (Jawa-Indonesia). Second, there are a variety of esthetic elements employed in wedding speech discourse. Third, changes in wedding speech discourse result from the underlying contexts.
\end{abstract}

Keywords: ceremonial discourse, Javanese wedding ceremony, expression of context

\section{PENDAHULUAN}

Pada umumnya bentuk komunikasi yang dilakukan manusia dapat dipilah menjadi dua, yaitu komunikasi verbal dan komunikasi nonverbal. Komunikasiverbalyaitucaraberkomunikasi seseorang dengan menggunakan bahasa lisan, atau kata-kata dan atau kalimat secara lisan. Sementara komunikasi nonverbal yaitu cara berkomunikasi dengan tanpa menggunakan kata-kata, cukup dengan isyarat atau tanda-tanda tertentu.

Pemilihan cara berkomunikasi itu sangat tergantung pada banyak faktor. Faktor yang dimaksud adalah hal-hal yang bersifat sosial (Halliday, 1992:24). Misalnya, usia, pekerjaan, tingkat sosial, latar, dan fungsi-fungsi sosial lainnya. Banyaknya faktor sosial yang harus diperhatikan menyebabkan munculnya berbagai bentuk variasi bahasa (secara sosiolinguistik) atau beragamnya jenis wacana (secara pragmatik). Masyarakat pemakai bahasa tampaknya tidak mengalami kesulitan untuk memilih dan menentukan bentuk bahasa atau wacana apa yang semestinya digunakan untuk komunikasi dalam situasi tertentu secara tepat. Masing-masing komunitas dalam segala masyarakat, termasuk masyarakat Jawa, akan dengan sendirinya menemukan konsensus sosial berkaitan dengan wacana yang digunakan sesuai dengan situasinya.

Berkaitan dengan pemilihan wacana dalam situasi dan fungsi sosial tertentu, masyarakat Jawa memiliki dan memelihara salah satu bentuk komunikasi yang bersifat sosial dan kultural. Bentuk komunikasi itu diungkapkan dengan cara melakukan aktivitas verbal sosio-kultural berupa pidato dalam upacara-upacara tertentu yang langsung berkaitan dengan aktivitas kehidupan masyarakat itu sendiri. Dalam pandang- 
an ilmu linguistik, ungkapan verbal atau pidato yang disampaikan pada saat-saat seremonial itu dapat digolongkan sebagai wacana seremonial (Mulyana, 2011:3).

Istilah "wacana seremonial" secara historis, dan dalam perkembangannya, menunjuk pada hasil pengembangan yang dikemukakan oleh Wedhawati (1979:42) terhadap pemilahan atau klasifikasi jenis wacana yang diuraikan oleh Longacre (1968) dalam laporan penelitiannya tentang bahasa-bahasa di Filipina dan wilayah Asia Tenggara lainnya yang berjudul "Discourse, Paragraph, and Sentence Structure in Selected Philippine Languages". Kemudian Kadarisman (1999), dalam disertasinya menggunakan istilah wedding narrative, untuk menyebut wacana pidato perkawinan. Jenis wacana dapat dipilah menjadi tujuh macam, yaitu wacana naratif, wacana prosedural, wacana ekspositori, wacana hortatori, wacana dramatik, wacana epistoleri, dan wacana seremonial. Wacana terakhir dianggap sebagai salah satu kekhasan jenis dan bentuk wacana dalam bahasa Jawa. Kekhasan itu menyangkut pemakaian ragam bahasa, bentuk keutuhan wacana, dan fungsi pemakaian wacana. Berdasarkan amatan yang telah dilakukan, pada umumnya wacana seremonial menggunakan ra-gam bahasa Jawa krama, dengan bebe-rapa ciri lain yang mengikutinya antara lain ragam bahasanya halus, bersopan santun, dan cenderung formal. Sementara itu, khusus untuk pidato perka-winan, di samping banyak menggunakan diksi literer, bahasa yang disampaikan bernada suka cita. Hal itu misalnya tampak pada bentuk wacana pidato perkawinan (PP) pambagyaharja (pidato penyambutan tamu) berikut ini. Kula ngaturaken pasegahan panakrama sugeng rawuh panjenengan sedaya, winantu ing agenging sembah nuwun awit saking keparenging rawuh. Wigato- sipun, panjenengan sadaya sami dipunsuwuni tambahing berkah saha pangestu konjuk dhumateng putra pinanganten. (PP-1/DL:2)

'Saya mengucapkan selamat datang kepada anda sekalian, teriring rasa terimakasih atas kesediaan anda untuk datang. Intinya, anda sekalian dimohon doa restunya untuk kedua pengantin.'

Sebagai sebuah bentuk wacana seremonial, pidato perkawinan (PP) memperlihatkan adanya aspek-aspek pengutuh wacana. Aspek-aspek itu antara lain adalah keutuhan struktur, keutuhan makna, dan keutuhan informasi. Secara struktural, teks pada PP merupakan satu keutuhan yang terdiri dari tiga bagian utama, yaitu: bagian awal (pendahuluan), bagian isi (utama), dan bagian akhir (penutup). Aristoteles, dalam bukunya yang berjudu Poetics juga menjelaskan bahwa sebuah karangan yang utuh, termasuk di dalamnya pidato, pada umumnya terdiri dari tiga bagian utama, yaitu bagian awal, tengah dan akhir (Syafe'ie, 1988:85). Bagianbagian tersebut dihubungkan dan disatukan oleh berbagai aspek pengutuh wacana yang bersifat internal dan eksternal secara komprehensif. Aspek-aspek inilah yang sangat perlu dideskripsikan dan atau dijabarkan secara lengkap dan jelas untuk mendapatkan gambaran utuh tentang teks dan konteks PP dalam bahasa Jawa secara lengkap.

Berdasarkan amatan yang telah dilakukan, ditemukan adanya beberapa gejala menarik berkaitan dengan keberadaan PP dalam masyarakat Jawa, terutama di Yogyakarta. Gejala tersebut antara lain berhubungan dengan masalah bentuk, ciri seremonial teks pidato, dan kenyataan adanya perubahan yang terus terjadi dalam PP itu sendiri. Wacana atau teks PP dalam bahasa Jawa memperlihatkan adanya pemakaian ragam bahasa Jawa krama yang halus, 
khas dan formal. Pemilihan ragam bahasa ini sangat mungkin berkaitan dengan pemakaian teks itu dalam sebuah acara seremonial resmi. Sebagaimana yang terjadi dalam masyarakat Jawa, pemakaian atau pemilihan ragam krama pada umumnya terjadi apabila orang yang berbicara merasa perlu menghormati orang lain yang diajak berbicara. Upacara perkawinan, dapat dikatakan sebagai wahana komunikasi antarorang yang saling menghormati. Dalam situasi tersebut, sangat wajar apabila ragam bahasa yang digunakan bersifat formal. Keformalan itu pada gilirannya menjadi salah satu faktor terbentuknya teks PP menjadi sebuah wacana yang utuh dan lengkap.

Bentuk formal teks PP menunjukkan ciri-ciri pemakaian bahasa yang indah, tata bahasanya relatif benar, struktur kalimat yang digunakan panjangpanjang, dan dilihat segi kewacanaannya, bentuk PP memiliki kelengkapan unsur-unsur wacana. Kelengkapan unsur kewacanaan menjadi syarat sebuah bentuk kebahasaan diterima sebagai wacana atau bukan (Brown, 1983:14; Edmondson, 1981:32). Keindahan bahasa antara lain terletak pada diksi (pilihan kata), misalnya masih digunakannya kosakata Kawi (bahasa Jawa lama), permainan bunyi (purwakanthi), dan gaya bahasa. Sekarang ini, seiring dengan perjalanan waktu, perubahan zaman, dan berbagai kondisi lain yang melatarbelakangi kehidupan masyarakat Jawa pada umumnya, bentuk teks PP dan jalannya (tatacara) upacara perkawinan adat Jawa telah banyak mengalami perubahan. Perubahan itu dapat dilihat terutama sekali pada sifat upacara (seremoni) itu sendiri. Upacara perkawinan yang dulu dianggap sakral, sekarang ini mengalami perubahan. Kondisi seperti inilah yang melahirkan sebuah pertanyaan: bagaimana perubahan konteks dapat mempengaruhi perubahan ben- tuk teks PP? Oleh karena itu kajian tentang teks dan konteks PP dalam bahasa Jawa diharapkan dapat menghasilkan temuan-temuan dan jawaban terhadap masalah tersebut.

\section{METODE}

Data penelitian yang dikaji berbentuk lisan dan data tulis. Data lisan diperoleh dari tuturan langsung wacana pidato perkawinan yang dapat dijangkau dalam masa penelitian berlangsung. Data tulis diperoleh dari berbagai buku, majalah, koran, atau sumber tertulis lain yang memuat pidato perkawinan. Sumber tertulis tersebut antara lain adalah: (1) Gita Wicara Jawi (Suwarna, 2003), (2) Tuladha Pambiwara Hamicara (KRT Prodjosoeranto, 2005), (3) Sesorah Tatacara (Tejawarsita, 1993), (4) Tuntunan Sesorah saha Panata titi Laksana (Sutardja, 2003). Data tulis (pustaka) tersebut dipilih dan digunakan sebagai bahan penelitian karena struktur bahasa, estetika, dan variasi pidato dinilai representatif.

Seting atau lokasi untuk melakukan penelitian ini adalah wilayah Daerah Istimewa Yogyakarta. Selanjutnya wilayah ini dijadikan sebagai populasi penelitian. Untuk mendapatkan data yang mewakili wilayah penelitian yang relatif luas tersebut, dilakukan pengambilan data dari kelima wilayah DIY tersebut, yatu Kota Yogyakarta, Kabupaten Sleman, Kulon Progo, Bantul, dan Gunung Kidul. Data diambil dari setiap wilayah tersebut dengan memperhitungkan aspek-aspek: variasi budaya, kotadesa, model upacara, dan pelaku upacara. Situasi yang variatif ini diharapkan dapat terkumpul hasil data yang juga variatif dan representatif. Penyediaan data dilakukan dengan tiga langkah, yaitu: pengumpulan data, pencatatan data, dan penyeleksian data.

Pengumpulan data dilakukan dengan metode simak terhadap PP yang telah ditentukan sebagai sampel (Sudar- 
yanto, 1993). Pada langkah ini tuturan teks PP disimak secara langsung (observasi) di lokasi berlangsungnya acara seremonial tersebut. Untuk menjaring dan mengumpulkan berbagai informasi yang penting, dilakukan wawancara dengan informan yang representatif (diantaranya dengan lima orang pranatacara profesional, dan sejumlah tokoh masyarakat yang paham benar masalah upacara perkawinan). Informasi penting tersebut menyangkut berbagai hal, antara lain: gaya upacara perkawinan yang diselenggarakan, para pelaku pidato, latar belkakang dan sikap pelaku pidato, asal calon pengantin pria, rancangan acara dan prediksi waktu upacara yang akan digelar.

Data yang telah tersedia kemudian dianalisis, dengan melewati langkah awal klasifikasi, yaitu: (1) memilahkan wacana PP berdasarkan jenis, (2) memilahkan wacana berdasar bentuk, pola estetika, dan konteks. Data yang telah berhasil diklasifikasi, kemudian dianalisis dengan metode dan teknik yang berkaitan dengan prinsip-prinsip analisis wacana. Sebagai sebuah gejala sosial, pidato dalam upacara perkawinan perlu dilihat berdasar hal-hal yang berkaitan dengan kemunculannya. Dengan kata lain, analisis data yang digunakan untuk mengurai pemakaian bahasa PP adalah metode kontekstual. Asumsi dan dasar pijakan utama analisis ini ialah menempatkan data selalu menyatu dengan konteks terjadinya tuturan. Metode lain yang digunakan dalam analisis ini ialah teknik-teknik analisis wacana (discourse analysis). Teknik dan atau prinsip-prinsip dalam analisis wacana digunakan untuk menjelaskan segala sesuatu yang menjadi faktor pengutuh PP, tujuan pemakaian wacana seremonial, keutuhan bentuk, dan perubahan bentuk yang terjadi karena perbedaan konteks seremonial. Khusus pemahaman tentang karakter dikaji dengan pendekatan kualitatif, untuk mendapatkan nilai-nilai sikap mental dan karakter para pelaku pidato perkawinan.

\section{HASIL DAN PEMBAHASAN}

Berdasarkan penelusuran penelitian dan analisis data yang telah dilakukan, diperoleh hasil penelitian yang menggambarkan tiga hal yang substansial, yaitu: (1) pemakaian bahasa, (2) estetika wacana, dan (3) konteks wacana dan perubahannya. Dalam penelitian ini sejumlah aspek terkait dengan ketiga hal tersebut diungkap, dikaji, dan dianalisis dengan pendekatan analisis wacana dan sosiolinguistik. Analisis ini akhirnya menghasilkan pemahaman dan kesimpulan ilmiah terkait dengan keberadaan dan perkembangan wacana pidato dalam upacara perkawinan masyarakat Jawa.

\section{Pemakaian Bahasa}

Bahasa Jawa digunakan dalam seluruh rantamaning adicara (rangkaian acara) upacara perkawinan. Pada umumnya, pidato dalam upacara perkawinan Jawa dibagi menjadi dua bagian; yaitu (1) pidato yang dilakukan oleh pranatacara (master of ceremony) dan (2) pidato yang dilakukan oleh orang yang ditunjuk untuk menyampaikan pidatonya.

Penggunaan bahasa Jawa penuh dan runtut (baik, benar dan tanpa campuran dengan bahasa lain), pada umumnya terjadi, antara lain karena kedua pihak besan (yang melaksanakan hajat dengan besannya) sama-sama orang Jawa. Pada kondisi semacam ini akan terjadi semacam kesepakatan tak tertulis, bahwa bahasa yang digunakan dalam upacara perkawinan adalah bahasa Jawa. Umumnya, pemakai pertama dan dianggap sebagai pelopor pemakaian bahasa Jawa (ragam krama inggil) adalah pranatacara sendiri. Hal itu tampak dalam kata pembuka adicara man- 
Tabel 1. Bentuk wacana Pidato Perkawinan Adat Jawa

\begin{tabular}{ll}
\hline \multicolumn{1}{c}{ Aspek } & \multicolumn{1}{c}{ Indikator Hasil } \\
\hline Bahasa wacana PP & Pemakaian bahasa dalam PP: \\
& Bahasa Jawa, \\
& Bahasa Indonesia, \\
& Bahasa Jawa-Indonesia \\
Estetika wacana PP & Penggunaan unsur-unsur susastra Jawa: \\
& tembung saroja, \\
& tembung garba, \\
& yogyaswara, \\
& keratabasa, \\
& tembung entar, \\
& paribasan, \\
& bebasan, \\
& saloka, \\
& pepindhan, \\
& pralambang, \\
& purwakanthi, \\
& panambang bunyi ha-, \\
seselan -in-, \\
seselan-um-, \\
tembung kawi, \\
diksi religiusitas. \\
Berubahnya bentuk dan substansi wacana pidato \\
perkawinan: \\
penutur, \\
tempat, \\
waktu, \\
orientasi nilai upacara, \\
gaya tuturan. \\
\\
\end{tabular}

ten menyambut kedatangan para tamu berikut.

Nuwun, ngaturaken pambagya sugeng rawuh konjuk dhumateng para tamu kakung saha putri ingkang dahat kinurmatan....(PP-1)

'Permisi, (kami) menyampaikan ucapan selamat datang kepada para tamu Bapak dan Ibu sekaliyan yang terhormat...'
Bahasa Indonesia juga digunakan dalam upacara perkawinan masyarakat Jawa, apabila menyangkut tiga hal, yaitu:

(1) Pihak besan berasal dari daerah yang masyarakatnya tidak menggunakan bahasa Jawa (luar Jawa, dsb),

(2) Penyelenggara hajat perkawinan menghadirkan tamu undangan yang sebagian besar dari komunitas for- 
mal (misalnya kalangan akademisi, perusahaan, relasi bisnis, dsb),

(3) Perubahan model upacara perkawinan (dari model tradisional ke model standing party).

Sementara itu, penggunaan bahasa campuran antara Jawa dan Indonesia (Jawindo) justru semakin menggejala. Fenomena kultural ini tidak lepas dari beberapa faktor, antara lain: (1) kesulitan berbahasa Jawa yang indah (rineng$g a)$, (2) menyesuaikan tuntutan jaman, (3) tujuan-tujuan tertentu. Gejala dipakainya bahasa campuran (Jawindo), terlepas dari nilai positif dan negatif, menunjukkan ada nilai perkembangan wacana perkawinan Jawa yang unik. Berikut salah satu contohnya.

Terimakasih, kami mewakili keluarga Bapak Dadang Sunandar di Tasikmalaya, menyampaikan ucapan terimakasih sekali lagi, sudah diterima dengan baik di sini. Mohon maaf, kula boten saged ngangge basa Jawa sing sae, kula boten isa apik yen ngginaken basa Jawa. Takut salah. Jadi dengan bahasa Indonesia saja ya. Saya teruskan...(PP-2)

\section{Aspek Estetika Wacana PP}

Berdasarkan kategori dan bukti linguistik yang berkembang di masyarakat, maka bahasa yang digunakan dalam upacara perkawinan Jawa dapat dimasukkan ke dalam kategori basa rinengga. Beberapa aspek yang berhasil ditemukan sebagai argumentasi bahwa wacana ini termasuk jenis wacana yang indah (estetis) adalah adanya penggunaan aspek-aspek susastra Jawa. Sejumlah aspek penentu keindahan wacana pidato dalam upacara perkawinan Jawa yang dapat ditemukan dalam penelitian ini antara lain adalah: 1) tembung saroja, 2) tembung garba, 3) yogyaswara, 4) keratabasa, 5) tembung entar, 6) paribasan, 7) bebasan, 8) saloka, 9) pepindhan, 10) pralambang, 11) purwakanthi (purwakanthi swara, purwakanthi sastra, purwakanthi lumaksita), 12) penambahan bunyi ha-, 13) seselan -in-, 14) seselan-um-, dan 15) tembung kawi.

Pemakaian aspek susastra Jawa terbukti mampu mengubah sebuah bahasa pidato dari bernilai 'biasa' menjadi 'luar biasa' (baca=lebih indah dan bernilai estetik). Bandingkan ucapan berikut ini. Wacana (1) dengan bahasa Jawa Krama inggil biasa, dan (2) dengan bahasa Jawa rinengga (indah).

(1) Penganten kakung sampun jumeneng saking kursi lenggahanipun, lajeng nganthi garwanipun sowan dhumateng para pepundhen. Kajengipun badhe sungkem sukunipun ingkang eyang saha rama ibu.

(2) Penganten kakung wus jengkar saking dhampar kencana, hanganthi ingkang garwa gyalumarap ngabyantara mring para pepundhen. Esthining penggalih, muhung sumedya sumungkem hanguswa pepadaning ingkang eyang miwah rama ibu. (PP-5)

'Pengantin pria sudah berdiri dari tempat duduknya (singgasana), lalu menggandeng istrinya menghadap para sesepuh. Maksud hatinya, berniat sujud bakti mencium kaki eyang dan bapak ibu(nya)'.

Diksi literer yang digunakan pada wacana (2) misalnya dhampar kencana 'kursi singgasana emas' adalah tembung entar (kata kias) yang dipilih untuk menciptakan penggambaran agung tempat duduk pengantin bagaikan singgasana raja yang megah. Dipakai juga penambahan bunyi ha- dan sisipan -um-, pada kata-kata tertentu agar tercipta efek estetis dan arkais sekaligus; misalnya kata nganthi 'menggandeng', nguswa 'mencium', sedya 'berniat', dan sungkem 'sujud bakti', diubah dengan pola tersebut menjadi hanganthi, hanguswa, sumedya, dan sumungkem 


\section{Konteks Wacana Pidato Perkawinan Jawa}

Konteks wacana pidato berpengaruh langsung dalam bentuk dan corak pidato dalam upacara perkawinan. Hasil penelitian ini menunjukkan, bahwa perubahan bentuk pidato dan konteks tata cara pelaksanaan upacara perkawinan itu sangat dipengaruhi oleh sejumlah komponen tutur, yaitu penutur, tempat, waktu, orientasi nilai, dan gaya pidato perkawinan.

Penutur pidato berpengaruh besar terhadap sumbangan perubahan pidato; artinya, siapa akan mengatakan bagaimana adalah rumus bentuk perubahan pidato perkawinan. Misalnya, kalau penutur pidato adalah seorang pejabat formal, biasanya bahasanya lebih ketat, lebih formal, dan cenderung kaku. Berdasarkan hasil penelitian, penutur yang berpengalaman berbicara di depan umum (misalnya ustadz, kyai) bahasanya tampak lebih bebas, cenderung humoris, dan mengalir. Aspek tempat, waktu, orientasi, dan gaya juga berpengaruh besar mengubah bentuk pidato sesuai dengan aspek tersebut. Pada intinya, perubahan pidato dan bentuk upacara perkawinan dapat dipilah menjadi tiga kategori konteks yang melatarbelakanginya, yaitu: (1) perubahan konteks karena penambahan, (2) perubahan konteks karena pengurangan, dan (3) perubahan konteks karena penggabungan beberapa tatacara dan acara.

Makna 'penambahan', dalam penelitian ini yang dimaksud adalah adanya sejumlah acara yang ditambahkan dalam upacara perkawinan yang dilaksanakan oleh masyarakat. Misalnya diselipkannya acara musik populer, humor, pengajian, dan sebagainya. Indikator makna penambahan dapat dikemukakan dengan didasarkan pada tata upacara perkawinan tradisional Jawa yang dianut masyarakat Jawa pada umumnya. Artinya, acara yang dianggap se- harusnya tidak ada atau secara historis tidak ada, namun sekarang muncul, sehingga hal tersebut dapat dianggap sebagai acara penambahan.

Makna 'pengurangan' dalam tata upacara perkawinan bersifat sebaliknya. Sejumlah acara yang seharusnya ada, namun ditiadakan, sehingga kondisi tersebut dapat dianggap sebagai 'pengurangan'. Beberapa acara yang biasanya dikurangi atau ditiadakan misalnya: sungkeman, kacar-kucur, pasrah tampi, dan sejumlah upacara adat lainnya. Berdasarkan penelusuran penelitian di lapangan diperoleh keterangan, bahwa pengurangan acara adat, sebagian besar karena acara-acara tersebut dirasakan semakin kurang efektif, menambah biaya, dan memakan waktu lama. Perhitungan ini tampaknya semakin menjadi pegangan masyarakat Jawa dalam melaksanakan upacara perkawinan.

Sementara itu, makna 'penggabungan' adalah munculnya jenis upacara perkawinan Jawa yang dilaksanakan dengan sejumlah gabungan gaya. Misalnya gaya Jawa, barat, dan gaya muslim. Penggabuangan gaya ini memberi konsekuensi munculnya sejumlah acara di dalamnya, misalnya: pasrah tampi tetap ada, namun ada sajian hiburan musik populer dengan cara makan ala orang barat, standing party (makan sambil berdiri dengan menikmati sajian hiburan musik atau lainnya). Namun, secara garis besar, perubahan-perubahan pada upacara perkawinan tersebut tetap disinyalir tidak atau belum terlalu jauh meningalkan pakem (pedomam moral dan kultural sebuah tradisi).

\section{SIMPULAN}

Berdasarkan uraian dalam pembahasan di depan, berikut ini disajikan sejumlah kesimpulan yang diharapkan dapat menjadi bahan pemahaman akhir tentang fokus penelitian ini. Wacana pidato yang disampaikan dalam upacara 
perkawinan biasanya menggunakan bahasa Jawa. Namun, dalam beberapa kasus secara kontekstual, digunakan juga bahasa Indonesia, atau campuran Jawa-Indonesia (Jawindo). Berdasarkan hasil penelitian ini, dapat diprediksikan bahwa pada masa yang akan datang, penggunaan bahasa campuran (bahasa Jawa dengan bahasa lain, terutama bahasa Indonesia) akan semakin dominan. Namun, unsur-unsur estetika wacana (indah, literer, dan arkais) akan tetap dipertahankan. Pertimbangannya, aspek estetika adalah bagian utama dan penting yang menyebabkan sebuah upacara perkawinan memiliki nuansa berbeda dan bahkan sakral, bila dibandingkan dengan pidato-pidato biasa.

Akhirnya, hasil temuan penelitiaan ini kiranya dapat digunakan sebagai bahan penting bagi peneliti dan masyarakat luas. Sejumlah aspek hasil temuan penelitian ini: pemakaian bahasa, estetika kewacanaan, dan perubahan konteks harus dipertimbangkan dengan matang untuk mempersiapkan sebuah pidato perkawinan yang tepat, dan sebuah upacara perkawinan Jawa yang agung.

\section{UCAPAN TERIMAKASIH}

Penelitian ini dapat berlangsung lancar karena adanya sejumlah bantuan dari berbagai pihak. Oleh karena itu dalam kesempatan ini peneliti ingin menyampaikan rasa terima kasih yang setinggi-tingginya kepada para pranatacara sebagai informan langsung, sejumlah wedding organizer, Dikti yang memberi dana penelitian (beasiswa), dan sejumlah mahasiswa yang membantu langsung mencari dan menyunting data penelitian. Terakhir, rasa terima kasih juga setulusnya disampaikan kepada staf pascasarjana di FIB UGM yang membantu masalah administrasi penelitian. Semoga hasil penelitian ini dapat memberi manfaat yang relevan

\section{DAFTAR PUSTAKA}

Atmojo. 1991. Sekar Pahargyan Pengantin. Yogyakarta: Media Pustaka.

Bratawidjaja, Thomas Wijasa. 1995. Upacara Perkawinan Adat Jawa. Jakarta: Pustaka Sinar Harapan.

Brown, Gillian dan George Yule. 1983. Discourse Analysis. Cambridge: Cambridge University Press.

Edmonsond, Willis. 1981. Spoken Discourse. London: Longman.

Halliday, MAK dan Ruqaiya Hassan. 1992. Bahasa, Konteks dan Teks. Aspek-aspekBahasadalamPandangan Semiotik Sosial. Yogyakarta: Gadjah Mada University Press.

Halliday. MAK. 1978. Language as Social Semiotics. USA: Edward Arnold.

Kadarisman, A. Effendi. 1999. Wedding Naratives as Verbal Art Performance: Explorations in Javanese Poetics. Disertasi. Universitas of Hawaii.

Kodiron. 1989. Sekar Setaman. Tatacara Upacara Adat Jawa. Surakarta: Putra Angkasa.

Longacre, Robert E. 1968. Discourse, Paragraph, and Sentence Structure in Selected Philippine Languages. Santa Ana California: TheSummer Institute of Linguistics.

Pringgawidagda, Suwarna. 1998. Gita Wicara Jawi Pranatacara tuwin Pamedharsabda. Yogyakarta: Kanisius.

Respationo, Suyadi. 1994. Upacara Mantu Gagrag Surakarta. Semarang: Dahara Prize.

Sudaryanto. 1991. Metode dan Aneka Teknik Analisis Bahasa. Pengantar Penelitian Wahana Kebudayaan Secara Linguistis. Yogyakarta: Duta Wacana University Press.

Sutawijaya, Danang. R. 1990. Upacara Penganten Tatacara Kejawen. Semarang: Aneka Ilmu.

Suwarna. 2003. "Estetika Bahasa Pembawa Acara Pengantin Jawa", Laporan Penelitian FBS UNY. 
Suyadi, R. 1994. Sekar Setaman. Yatmana, Rama Sudi. 1988. Tuntunan Yogyakarta: CV Cendrawasih.

Syafe'ie, Imam. 1988. Retorika dalam Menulis. Jakarta: Departemen Pendidikan dan Kebudayaan. Kagem Para Panatacara tuwin Pamedharsabda. Semarang: Aneka Ilmu. 